ACTA MYCOLOGICA

Vol. 44 (2): 179-184

2009
Dedicated with pleasure to Professor Krystyna Czyżewska not only for her significant contribution to the knowledge and conservation of Polish lichens,

but also for her activities in cooperation networks of Central European lichenologists

\title{
Some lichens from the vicinity of Ribeiro Frio (Madeira, Macaronesia)
}

\author{
IVAN PIŠÚT \\ Institute of Botany, Slovak Academy of Sciences, Dúbravská cesta 14 \\ SK-84523 Bratislava, ivan.pisut@savba.sk
}

Pišút I.: Some lichens from the vicinity of Ribeiro Frio (Madeira, Macaronesia). Acta Mycol. 44 (2): 179-184, 2009.

A list of 49 lichens recently collected in the vicinity of Ribeiro Frio in Madeira is given. The species Ramalina nodosa and Peltigera neckeri are probably new to the island. Collections of Cladonia stereoclada, Hypogymnia madeirensis, Megalospora maderensis, Peltigera degenii and Phlyctis agelaea are interesting as well.

Key words: lichenized fungi, Madeira, Portugal

\section{INTRODUCTION}

Madeira is a Portuguese island in the Atlantic ocean, $900 \mathrm{~km} \mathrm{SW}$ of Portugal and $660 \mathrm{~km}$ NNW of the Canary Islands (Fig. 1). In winter 2002 and 2003 I had an opportunity to study lichens at some localities during my short holidays in Madeira (Pišút 2004). In 2008 and 2009 I visited the island again and studied the lichens of the laurel forests near the habitation of Ribeiro Frio situated below Poiso, a mountain transition in the northern part of the island on the road between Funchal and Santana. In 2008 I studied the lichens along the levada between Ribeiro Frio and Portello (1), in 2009 on the levada between Ribeiro Frio and Balcões (2) and in the laurel forest above the habitation (3). The material is preserved in my herbarium and in lichen collections of the Institute of Botany, Slovak Academy of Sciences, Bratislava (SAV). 


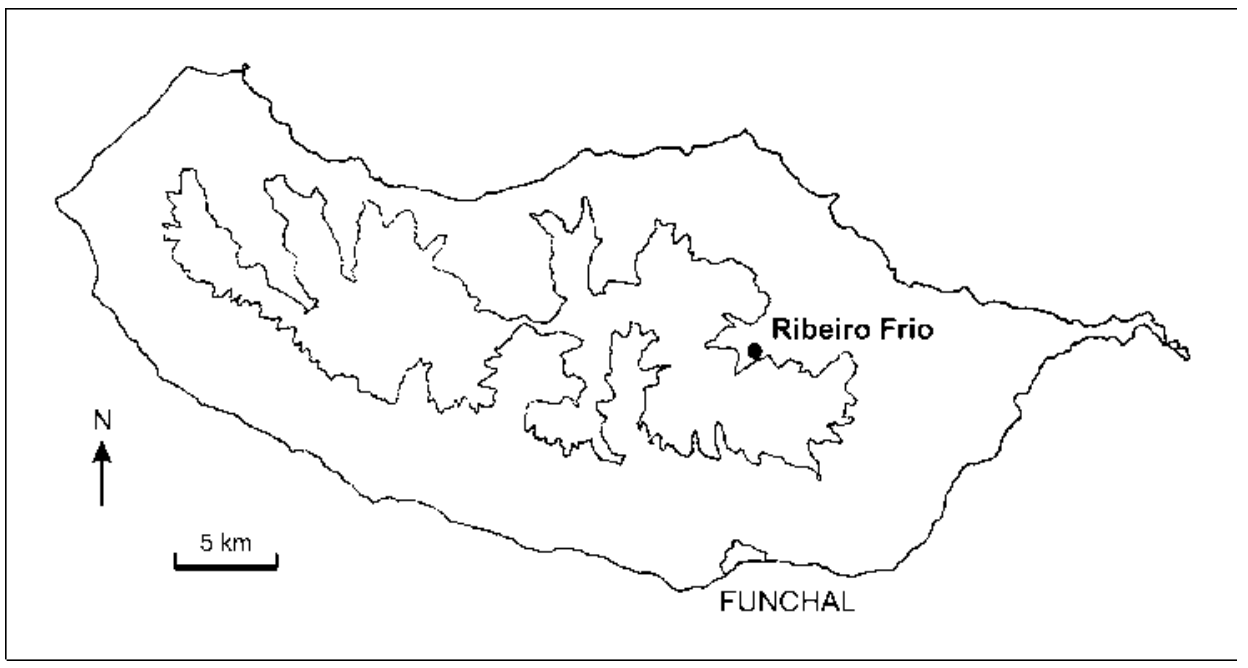

Fig. 1. Sketch map of Madeira. Areas above $1000 \mathrm{~m}$ altitude within the internal line. Adapted from Arvidsson and Wall (1985).

\section{RESULTS AND DISCUSSION}

Data on 49 lichen species are presented. The species Ramalina nodosa and Peltigera neckeri are probably new to the island; other findings, e.g., Cladonia stereoclada, Hypogymnia madeirensis and Megalospora maderensis, are also interesting.

Byssoloma leucoblepharum (Nyl.) Vain. - on leaves of Laurus azorica above Ribeiro Frio, alt. ca $920 \mathrm{~m} \mathrm{(3).}$

B. subdiscordans (Nyl.) P. Jameson - on leaves of Laurus azorica $2 \mathrm{~km}$ east of Ribeiro Frio, alt. ca $830 \mathrm{~m} \mathrm{(1);} \mathrm{on} \mathrm{leaves} \mathrm{of} \mathrm{Laurus} \mathrm{azorica} \mathrm{and} \mathrm{Ilex} \mathrm{canariensis} \mathrm{above}$ Ribeiro Frio, alt. ca 900 m (3).

Cetrelia olivetorum (Nyl.) W. L. Culb. \& Ch. F. Culb. - on tree bark (Lauraceae) ca 1 $\mathrm{km}$ east of Ribeiro Frio, alt. $850 \mathrm{~m}$ (1).

Cladonia rangiformis Hoffm. - among mosses on basaltic rocks, ca $2 \mathrm{~km}$ eastwards, alt. 830 m, and near Ribeiro Frio, alt. 880 m, 2008 (1); C. stereoclada des Abb. on mossy basaltic rocks ca $1 \mathrm{~km}$, alt. ca $850 \mathrm{~m}$, and on earth ca $2 \mathrm{~km}$, alt. ca 830 m, east of Ribeiro Frio (1); on mossy basaltic rocks above Ribeiro Frio, alt. ca 900 and $920 \mathrm{~m} \mathrm{(3)}$, sparse. This Macaronesian endemic species was described by des Abbayes (1946) from the Faial island in the Archipelago of the Azores. He characterized it as follows: "Cette intéressante espèce est incontestament voisine de $\mathrm{Cl}$. furcata, notamment par ses réactions et ses conidanges. Mais elle en est distincte par ses podétions beacoup plus ténus, semi-pellucides, et surtout par sa couche chondroïde formant un axe plein, et lorsque' elle est creuse, toujours très épaisse par suite de 1'exigüité de la cavité centrale". C. stereoclada was recorded in Madeira by Tavares (1952) for the first time (4 localities on mossy earth at alt. 828-1000 m) and in the Canaries by Østhagen and Krog (1976). 
Degelia plumbea (Lightf.) P. M. Jørg. \& P. James - on humid basaltic rocks and on tree bark (Lauraceae) $2 \mathrm{~km}$ east of Ribeiro Frio, alt. $830 \mathrm{~m} \mathrm{(1).}$

Fellhanera bouteillei (Desm.) Vězda - on leaves of Laurus azorica $2 \mathrm{~km}$ eastwards, alt. ca 830 m (1), and above Ribeiro Frio, alt. ca 920 m (3).

Heterodermia leucomelos (L.) Poelt - on branches and the bark of various laurels and on mossy basaltic rocks, alt. 850-880 m (1), on the bark of various Lauraceae, alt. $900 \mathrm{~m}$; abundant (3).

Hypogymnia madeirensis (Tav.) Hawks. - on dry branches of a deciduous tree (Lauraceae) ca $2 \mathrm{~km}$ east of Ribeiro Frio, alt. ca $830 \mathrm{~m}$ (1). My specimen lacks soredia, contains a few stalked apothecia and its medulla is PD-. H. madeirensis shows some superficial similarity to $H$. tavaresii, but the latter is larger and its medulla reacts PD+ bright yellow (Hawksworth 1973). Tavares (1952) recorded this species (as Parmelia madeirensis) from its locus classicus ("Inter Queimadas et Calderario Verde, ad ramos Ericae circ. 900 m s. m. 9-VIII-1951").

Hypotrachyna endochlora (Leight.) Hale - on Ocotea foetens bark ca $1 \mathrm{~km}$ east of Ribeiro Frio, alt. ca $850 \mathrm{~m}$ (1). From Madeira for the first time recorded by Arvidsson and Wall (1985) in Ribeiro Frio; H. laevigata (Sm.) Hale - on mossy basaltic rocks ca $2 \mathrm{~km}$ east of Ribeiro Frio, alt ca $830 \mathrm{~m} \mathrm{(1).} \mathrm{From} \mathrm{Madeira} \mathrm{for}$ the first time recorded as Parmelia laevigata by Alstrup (1991) in Ribeiro Frio; $\boldsymbol{H}$. pulvinata (Fée) Hale - among mosses on basaltic rocks $2 \mathrm{~km}$, alt. ca $830 \mathrm{~m}$ and 1 km, alt. ca $850 \mathrm{~m}$, east of Ribeiro Frio (1). Probably already recorded by Tavares (1964, as H. taylorensis). H. pulvinata is absent in Madeira in Hafellner's checklist (1995), but it occurs there according to Schumm (2008). The only difference between $H$. pulvinata and $H$. taylorensis is the upper surface of older specimens of the latter with occasional irregular white abraded areas. They are probably symptoms of altering according to Schumm (1.c.). REMARK. If both species are identical, the binom Parmelia pulvinata Fée 1824 has priority against Parmelia taylorensis M. E. Mitsch. 1961; H. rockii (Zahlbr.) Hale - on the bark of Laurus azorica, $2 \mathrm{~km}$ east of Ribeiro Frio, alt. ca $830 \mathrm{~m} \mathrm{(1).} \mathrm{For} \mathrm{the} \mathrm{first} \mathrm{time} \mathrm{recorded}$ from Madeira in the laurel forest (several collections) by Arvidsson and Wall (1985).

Leptogium brebissonii Mont. - on mossy basaltic rock above Ribeiro Frio, alt. ca 900 m (3); L. cochleatum (Dick.) P. M. Jørg. \& P. James - on mossy basaltic rocks and on the bark of Laurus azorica $2 \mathrm{~km}$ east of Ribeiro Frio, alt. $830 \mathrm{~m} \mathrm{(1);} \mathrm{on} \mathrm{cedar}$ bark near Ribeiro Frio, alt. 880 m (1); on mossy basalt rock above Ribeiro Frio, alt. ca 900 m (3); L. cyanescens (Rabh.) Körb. - on cedar bark near Ribeiro Frio, alt. ca $880 \mathrm{~m}$ (1).

Lobaria immixta Vain. - on branches of Ocotea foetens $2 \mathrm{~km}$ east of Ribeiro Frio alt. ca $830 \mathrm{~m} \mathrm{(1);} \mathrm{on} \mathrm{branches} \mathrm{of} \mathrm{Ocotea} \mathrm{foetens} \mathrm{and} \mathrm{Laurus} \mathrm{azorica} \mathrm{above} \mathrm{Ribeiro}$ Frio, alt. ca $900 \mathrm{~m} \mathrm{(3);} \mathrm{L.} \mathrm{sublaevis} \mathrm{(Nyl.)} \mathrm{Tav.} \mathrm{-} \mathrm{on} \mathrm{the} \mathrm{bark} \mathrm{of} \mathrm{a} \mathrm{deciduous} \mathrm{tree}$ (Lauraceae) $2 \mathrm{~km}$ east of Ribeiro Frio, alt. $830 \mathrm{~m} \mathrm{(1);} \mathrm{on} \mathrm{fallen} \mathrm{tree} \mathrm{branches}$ (Lauraceae) between Ribeiro Frio and Balcões, alt. $850 \mathrm{~m}$ (2); on the bark of Laurus azorica above Ribeiro Frio, alt. ca 900 m (3).

Megalospora maderensis (Krempelh.) Sipman - on the bark of Ocotea foetens ca 1 km east of Ribeiro Frio, alt. ca 850 m (1).

This rare endemic species in Madeira is characterized with by bacillar spores, the presence of clearly thickened edges around the spore septa and the presence of 
usnic acid (Sipman 1983). It occurs at elevations from 850 to $1000 \mathrm{~m}$ on bark and rock (Tavares 1952, as Bombyliospora amplificans var. maderensis).

Nephroma foliolatum P. James \& F. J. White - on fallen branches of a deciduous tree (Lauraceae), alt. ca $850 \mathrm{~m}$ (2); among mosses on the bark of Laurus azorica above Ribeiro Frio, alt. ca 900 m (3). According to James and White (1987), Nephroma foliolatum is confined to the laurel forest of Madeira. It is also known from a single unlocalized gathering collection from the Canary Islands; $N$. laevigatum Ach. - on a wooden fence near Ribeiro Frio, alt. ca 880 m (3).

Normandina pulchella (Borrer) Nyl. - on the thallus of Degelia plumbea growing on tree bark (Lauraceae) above Ribeiro Frio, alt. ca 900 m (3); as a facultative lichen growing on lichens.

Ochrolechia pallescens (L.) A. Massal. - on fallen branches of deciduous trees (Lauraceae) ca 2 km east of Ribeiro Frio, alt. 830 m, and near Ribeiro Frio, alt. $880 \mathrm{~m}$ (1).

Pannaria rubiginosa (Ach.) Bory - among mosses on the bark of Laurus azorica, alt. ca $850 \mathrm{~m} \mathrm{(2)}$; on the bark of Ocotea foetens above Ribeiro Frio, alt. ca $900 \mathrm{~m} \mathrm{(3).}$

Parmelia saxatilis (L.) Ach. - on mossy basaltic rock above Ribeiro Frio, alt. ca $900 \mathrm{~m} \mathrm{(3).}$

Parmotrema arnoldii (Du Rietz) Hale - on tree bark (Lauraceae), ca $2 \mathrm{~km}$ east of Ribeiro Frio, alt. 830 m (1); P. perlatum (Huds.) M. Choisy - on branches of a deciduous tree (Lauraceae) near Ribeiro Frio, alt. 880 m, (1); on mossy basaltic rock above Ribeiro Frio, alt. ca $900 \mathrm{~m} \mathrm{(3);} \mathrm{P.} \mathrm{robustum} \mathrm{(Degel.)} \mathrm{Hale} \mathrm{-} \mathrm{on} \mathrm{tree}$ bark (Lauraceae), ca $1 \mathrm{~km}$ east of Ribeiro Frio, alt. ca $850 \mathrm{~m}$ (1).

Peltigera degenii Gyeln. - among mosses on basaltic rock $1 \mathrm{~km}$ east of Ribeiro Frio, alt. $850 \mathrm{~m}$ (1). In Madeira so far recorded only on mossy stones along the road in Cruzinhas, at alt. ca $550 \mathrm{~m}$ (Alstrup 1991); P. membranacea (Ach.) Nyl. - on mosses on basaltic rock above Ribeiro Frio, alt. ca 900 m (3); P. neckeri Hepp ex Müll. Arg. - on mossy basaltic rocks near Ribeiro Frio, alt. 880 m (1).

Pertusaria leucostoma (Bernh.) A. Massal. - on fallen branches of a deciduous tree (Lauraceae), ca $1 \mathrm{~km}$ east of Ribeiro Frio, alt. ca $850 \mathrm{~m}$ (1); P. ophthalmiza (Nyl.) Nyl. - on branches of Laurus azorica, 2 km east of Ribeiro Frio, alt. ca $830 \mathrm{~m} \mathrm{(1);}$ on the bark of Ocotea foetens between Ribeiro Frio and Balcões, alt. ca $850 \mathrm{~m}$ (2). From the second site probably already recorded by Tavares (1952) on introduced Platanus (as P. multipuncta).

Phlyctis agelaea (Ach.) Flot. - on dry braches of Ocotea foetens ca $2 \mathrm{~km}$ east from Ribeiro Frio, alt. ca 830 m (1).

For the first time recorded on flakes of Eucalyptus between Camacha and Carreiras by Arvidsson and Wall (1985).

Porina leptosperma Müll. Arg. - on leaves (Laurus azorica), alt. ca 920 m (3). According to Sérusiaux (1996), this otherwise pantropical species is common on the island.

Pseudocyphellaria aurata (Ach.) Vain. - on the bark of a deciduous tree (Lauraceae) $2 \mathrm{~km}$ east of Ribeiro Frio, alt. $830 \mathrm{~m} \mathrm{(1);} \mathrm{on} \mathrm{the} \mathrm{bark} \mathrm{of} \mathrm{Ocotea} \mathrm{foetens} \mathrm{above}$ Ribeiro Frio, alt. ca 900 m (3); P. crocata (L.) Vain. - on dry branches of a deciduous shrub above Ribeiro Frio, alt. ca 900 m (3); P. intricata (Delise) Vain. - on the bark of Laurus azorica above Ribeiro Frio, alt. ca $900 \mathrm{~m}$ (3). 
Ramalina farinacea (L.) Ach. - on fallen tree branches (Lauraceae), alt. ca $900 \mathrm{~m}$ (3); R. nodosa Krog \& Østhagen - on almost vertical basaltic slopes ca $2 \mathrm{~km}$ east of Ribeiro Frio, alt. ca $830 \mathrm{~m}$ (1). Probably new to Madeira, according to Krog and Østhagen (1980) and Aptroot and Schumm (2008); until now known only from the Canary Islands (Fuerteventura, Tenerife and Gomera). Ramalina nodosa is characterised by delicate, thin $(0.1-1 \mathrm{~mm})$, richly branched subterete to terete laciniae without soredia and pseudocyphellae, with numerous nodules; $\boldsymbol{R}$. subgeniculata $\mathrm{Nyl}$. - on fallen tree branches (Lauraceae), $1 \mathrm{~km}$ east of Ribeiro Frio, alt. $850 \mathrm{~m} \mathrm{(1)}$; in the levada between Ribeiro Frio and Balcões, alt. $850 \mathrm{~m}$ (2) and above Ribeiro Frio, alt. ca 900 m (3).

Rimelia reticulata (Taylor) Hale \& A. Fletscher - on a deciduous tree (Lauraceae) ca $1 \mathrm{~km}$ east of Ribeiro Frio alt. $850 \mathrm{~m}$ (1); on the bark of Ocotea foetens between Ribeiro Frio and Balcões alt. ca $850 \mathrm{~m}$ (2).

Stereocaulon azoreum (Schaer.) Nyl. - on basaltic rocks $1 \mathrm{~km}$ eastwards, alt. $850 \mathrm{~m}$ (1) and above Ribeiro Frio, alt. ca 900 m (3).

Sticta canariensis Bory ex Del. - on tree branches (Lauraceae) $1 \mathrm{~km}$ east of Ribeiro Frio, alt. $850 \mathrm{~m}$ (l) and abundantly on mossy rocks above Ribeiro Frio, alt. ca 900 $\mathrm{m}(3)$.

Tapellaria epiphylla (Müll. Arg.) R. Sant. - very frequent, e.g., on leaves of Laurus azorica $2 \mathrm{~km}$ east of Ribeiro Frio, alt. ca $830 \mathrm{~m} \mathrm{(1)}$; on leaves of Ocotea foetens, Ilex canariensis, Ilex perado, Persea indica and introduced Taxus baccata above Ribeiro Frio, alt. ca $900 \mathrm{~m}$ (3).

Thelotrema lepadinum (Ach.) Ach. - on the bark of Ocotea foetens between Ribeiro Frio and Balcões, alt. ca $850 \mathrm{~m} \mathrm{(2).}$

Usnea articulata Hoffm. - on fallen tree branches (Lauraceae) above Ribeiro Frio, alt. $900 \mathrm{~m} \mathrm{(3).}$

Usnea rubicunda Stirton - on fallen tree branches (Lauraceae) $2 \mathrm{~km}, 830 \mathrm{~m}$ and $1 \mathrm{~km}$ east of Ribeiro Frio, alt. ca $850 \mathrm{~m}$ (1); on fallen tree branches (Lauraceae) above Ribeiro Frio, alt. 900 m (3).

Woessia apiahica (Müll. Arg.) Sérus. - on tree leaves (Lauraceae) above Ribeiro Frio, alt. ca $900 \mathrm{~m}(\mathbf{3})$.

In Madeira already mentioned by Santesson (1952) as Bacidia apiahica.

Acknowledgement. I thank my son Ing. P. Pišút, $\mathrm{PhD}$ for his help in the field and for his comments on the manuscript. 


\title{
REFERENCES
}

Abbayes, des H. 1946. Les Cladonia (Lichens) des Iles Açorés. Port. Acta Biologica 1 (3/4): 243-254.

Alstrup V. 1991. Some lichens from Madeira. Graphis Scripta 3 (3): 108-109.

Aptroot A. F., Schumm F. 2008. Key to Ramalina species known from Atlantic islands, with two new species from the Azores [Bestimmungsschlüssel für Ramalina Arten von den atlantischen Inseln, mit zwei neuen Arten aus den Azoren]. Sauteria 15: 21-57.

Arvidsson L., Wall S. 1985. Contribution to the lichen flora of Madeira. Lichenologist 17: 39-49.

Hafellner J. 1995. A new checklist of lichens and lichenicolous fungi of insular Laurimacaronesia including a lichenological bibliography for the area. Fritschiana 5: 1-132.

Hawksworth D. L. 1973. Two new species of Hypogymnia (Nyl.) Nyl. Lichenologist 5: 452-456.

James P. W., White F. J. 1987. Studies on the genus Nephroma I. European and Macaronesian species. Lichenologist 19: 215-268.

Krog H., Østhagen H. 1980. The genus Ramalina in the Canary Islands. Norw. J. Bot. 27: 255-296.

Østhagen H., Krog H. 1976. Contribution to the lichen flora of the Canary Islands. Norw. J. Bot. 23: 221-242.

Pišút I. 2004. A few lichens from Madeira. Acta Rer. Natur. Mus. Nat. Slov. 50: 14-17.

Santesson R. 1952. Foliicolous lichens I. A revision of the obligately foliicolous, lichenized fungi. Symbolae Bot. Upsalienses 12 (1): 1-500.

Schumm F. 2008. Flechten Madeiras, der Kanaren und Azoren. Ed. Beck, OttG Süssen, 294 pp.

Sérusiaux E. 1996. Foliicolous lichens from Madeira with the description of a new genus and two new species and a world-wide key of foliicolous Fellhanera. Lichenologist 28 (3): 197-227.

Sipman H. M. 1983. A monograph of the lichen family Megalosporaceae. Biblioth. Lichenol. 18: 1-241 and Tables.

Tavares C. N. 1952. Contributions to the lichen flora of Macaronesia I - Lichens from Madeira. Port. Acta Biol. Sér. B, Sist. 3 (3): 308-391.

Tavares C. N. 1964. Contributions to the lichen flora of Macaronesia III - New or interesting taxa. Revista de Biologia 4 (1/2): 131-144.

\section{O niektórych porostach poznanych w okolicach Ribeiro Frio (Madera, Makaronezja)}

\begin{abstract}
Streszczenie
Podano listę 49 gatunków porostów zebranych w latach 2008 i 2009 w okolicy siedziby Ribeiro Frio na wyspie Madera. Gatunki Ramalina nodosa i Peltigera neckeri są prawdopodobnie nowe dla tej wyspy; interesujące są równieź notowania gatunków Cladonia stereoclada, Hypogymnia madeirensis, Megalospora maderensis, Peltigera degenii i Phlyctis agelaea.
\end{abstract}

